\title{
COMPETÊNCIAS LEGISLATIVAS E ANALOGIA - BREVE ENSAIO A PARTIR DE DECISÕES JUDICIAIS SOBRE A APLICAÇÃO DO ART. 54 DA LEI N. 9.784/99
}

\author{
LEGISLATIVE COMPETENCES AND ANALOGY - BRIEF ESSAY ON JUDICIAL APPLICATION OF \\ ACT N. 9.784/99, ART. 54.
}

Fernando Dias Menezes de Almeida ${ }^{1}$

\begin{abstract}
Resumo:
O presente ensaio analisa o modo pelo qual o Superior Tribunal de Justiça tem interpretado e aplicado o disposto no art. 54 da Lei n. 9.784/99, quanto ao limite temporal para que a Administração Pública anule seus atos. O desenvolvimento do ensaio parte da distinção entre analogia legis, analogia iuris e interpretação extensiva, para discutir a possibilidade de supressão de lacuna no Direito estadual por analogia em relação ao Direito federal, tendo como questão de fundo a existência ou-não, no Direito brasileiro, de norma principiológica que imponha prazo para que a Administração anule seus atos.

Palavras-chaves: Lei n. 9.784/99. Administração Pública. Analogia legis. Analogia iuris.

Abstract:

This essay analyses the interpretation and application given by the Superior Tribunal de Justiça to Act n. 9.784/99, art. 54, referring to the temporal limit for the Public Administration to nullify its acts. The essay starts from the distinction between analogia legis, analogia iuris and extensive interpretation, and discuss the possibility of suppressing a State Law blank employing analogically Federal Law, having as main question the existence or not, in Brazilian Law, of a principle that imposes a limit of time for the Administration to nullify its acts.
\end{abstract}

Keywords: Act n. 9.784/99. Public Administration.

A Lei federal n. 9.784/99, como é notório, constitui importante marco da evolução de nosso Direito Administrativo, introduzindo normas acerca do processo administrativo no âmbito da Administração Pública federal.

Essa lei cristalizou a tendência da ênfase na processualização da ação da Administração, no sentido da aplicação do direito fundamental ao devido processo legal (Constituição Federal, art. $5^{\circ}$, LIV e LV). ${ }^{2}$ E também cuidou de importantes pontos sobre

\footnotetext{
Professor Doutor do Departamento de Direito do Estado da Faculdade de Direito da Universidade de São Paulo.

2 Tema esse especialmente defendido e analisado na doutrina brasileira por MEDAUAR, Odete. $A$ processualidade no direito administrativo. São Paulo: Revista dos Tribunais, 1993; administrativo em evolução. 2. ed. São Paulo: Revista dos Tribunais, 2003. $O$ direito
} 
a matéria dos atos administrativos em geral, dando, assim, tratamento legislativo a temas que antes eram apenas objeto de construções doutrinárias e jurisprudenciais.

Em alguns desses pontos, a Lei trouxe inovações em relação a afirmações tradicionalmente acolhidas por parte substancial dos administrativistas. Tal se passa, por exemplo, com seu art. 54, que afasta a tese da ausência de limite temporal para a anulação - ou seja, desfazimento por razão de ilegalidade - dos atos administrativos: ${ }^{3}$

Art. 54. O direito da Administração de anular os atos administrativos de que decorram efeitos favoráveis para os destinatários decai em cinco anos, contados da data em que foram praticados, salvo comprovada má-fé.

$\S 1^{\circ}$ No caso de efeitos patrimoniais contínuos, o prazo de decadência contar-se-á da percepção do primeiro pagamento.

$\S 2^{\circ}$ Considera-se exercício do direito de anular qualquer medida de autoridade administrativa que importe impugnação à validade do ato.

Tratando-se de norma editada em 1999, não se está hoje, naturalmente, face a questão nova. Todavia, uma recente decisão judicial ${ }^{4}$ sugeriu-me um aspecto da questão sobre o qual não havia ainda refletido.

\section{O Diário da Justiça de 19 de março de 2007 (p. 381) traz acórdão proferido}

pelo Superior Tribunal de Justiça com a seguinte ementa:

\footnotetext{
E que assim - em conjunto com o art. 55: "Em decisão na qual se evidencie não acarretarem lesão ao interesse público nem prejuizo a terceiros, os atos que apresentarem defeitos sanáveis poderão ser convalidados pela própria Administração" - relativiza a noção de nulidade dos atos administrativos, reforçando o sentido de anulabilidade. Aliás, concordo com os autores que, num plano mais teórico, negam a existência de algo como a nulidade (cf. a notória objeção levantada por KELSEN, Hans. Teoria Pura do Direito. Tradução João Baptista Machado. Coimbra: Arménio Amado, 1962. v. 2, p. 159 e ss.). Tradicionalmente se propõe uma distinção entre nulidade e anulabilidade, sendo o "nulo" algo dado per se e o "anulável" algo constituído pela decisão da autoridade competente. Contudo, considerar algo como nulo per se, levando à mera constatação desse "fato" pela autoridade jurídica competente (v.g., juiz), contraria a natureza das coisas. Na realidade, o que se passa é que a decisão dessa autoridade competente é que manterá ou retirará a validade do ato. Se cabe a tal autoridade, por ato de vontade seu - posto que a interpretação e a conseqüente decisão judicial não são simples atos de conhecimento -, tomar tal decisão, então considerar que haja um nulo a priori é mera ficção. Além dessa distinção entre nulidade e anulabilidade, ora criticada, fundada em elemento essencial, há outras distinções que se referem a elementos circunstanciais. Assim, afirma-se que o vício de nulidade não é sanável, e o de anulabilidade, sanável; porém, afastada a noção de nulidade, seria desejável que, para se evitar dúvida terminológica, se falasse, nessa hipótese, em ato sanável (ou passível de convalidação) e não-sanável (ou-não passível de convalidação), mas sempre anuláveis. Outra questão circunstancial diz respeito aos efeitos do ato de invalidação: tradicionalmente se diz que a nulidade opera efeitos ex tunc, e a anulabilidade, ex nunc. Também aqui afastada a noção de nulidade, deve-se cogitar de anulação com ou sem efeitos retroativos. Nesse sentido, a retroação dos efeitos se dá por força de uma decisão a posteriori (tese da anulabilidade), e não por um fato a priori (tese da nulidade): do ponto de vista da realidade, há que se entender que efeitos do ato anulado existiram e serão desfeitos; e não que tais efeitos não existiram.

4 Para a qual chamou-me atenção a professora e minha orientanda em doutorado Vera Monteiro.
} 
PROCESSUAL CIVIL. ADMINISTRATIVO. LEI N. 9.784/99. ADMINISTRAÇÃO ESTADUAL.APLICAÇÃO. ANULAÇÃO DEATO ILEGAL PELAADMINISTRAÇÃO FEDERAL. DECADÊNCIA. NÃO-OCORRÊNCIA. RECURSO ESPECIAL CONHECIDO E IMPROVIDO.

1. O Superior Tribunal de Justiça possui entendimento firmado no sentido de que o prazo decadencial de 5 (cinco) anos para a Administração rever seus atos, nos termos da Lei n. 9.784/99, deve ser aplicado no âmbito estadual, quando ausente norma específica.

2. In casu, todavia, a revisão do ato ocorreu em 1996, antes, portanto, do advento do referido diploma legal. Aplicase, por conseguinte, a regra geral então vigente, segundo a qual a Administração poderia, a qualquer tempo, rever atos eivados de vícios que os tornam ilegais. Aplicação da Súmula n. 473/STF.

3. Recurso especial conhecido e improvido".

(REsp n. 610.464-DF, Rel. Min. Arnaldo Esteves Lima, Quinta Turma).

Em verdade, não pretendo discutir a questão de fundo desse julgado; nem esgotar uma análise de jurisprudência sobre a matéria da anulação dos atos administrativos. ${ }^{5}$ Tampouco cuidar de outros pontos relevantes envolvendo a aplicação do art. 54 da Lei n. 9.784/99. Mas sim analisar um aspecto relativo à repartição das competências legislativas dos entes federativos.

A tese sustentada no acórdão, como sintetizada em sua ementa, é a de que "o prazo decadencial de 5 (cinco) anos para a Administração rever seus atos, nos termos da Lei 9.784/99, deve ser aplicado no âmbito estadual, quando ausente norma específica".

A rápida leitura do acórdão no REsp n. 610.464, poderia levar à conclusão da qual, já adianto, eu discordaria, por entendê-la conflitante com as regras constitucionais sobre repartição de competências legislativas dos entes federativos - de que a Lei n. 9.784/99 impõe-se aos Estados, na ausência de lei estadual, numa espécie de aplicação invertida dos $\S \S 3^{\circ}$ e $4^{\circ}$ do art. 24 da Constituição. ${ }^{6}$

Parece-me, no entanto, não ser essa a melhor compreensão desse acórdão, em que pese seja sim essa a conclusão apresentada em outros mais abaixo analisados.

\footnotetext{
5 Há muitos exemplos de julgados de diversos tribunais sobre a aplicação desse art. 54. Por ora, tomo este julgado, que, com efeito, sequer configura caso com maior repercussão jurisprudencial, como ponto de partida para uma análise de um ponto específico por ele suscitado.

${ }^{6}$ E, de todo modo, aplicação descabida, não apenas por ausência de previsão constitucional a respeito - o que já é argumento suficiente -, mas também por sequer se tratar aqui, como se vai expor a seguir, de matéria de competência legislativa concorrente.
} 
O acórdão no REsp 610.464 é muito sucinto. Mas permite notar uma sutileza: fala-se na aplicação do prazo de 5 anos, nos termos da Lei n. 9.784/99, e não na aplicação da Lei.

Essa distinção fica mais clara com a análise de outro acórdão da mesma Turma, citado nesse ora comentado, cuja ementa é a seguinte:

ADMINISTRATIVO. SERVIDOR
FILHA PÚBLICO.
DEPENDENNCIA. PENSÃO PORA 21 ANOS.
INÉRCIA DA ADMINISTRAÇÃO. DECADÊNCIA
ADMINISTRATIVA. JUROS DE MORA.
PERCENTUAL. INÍCIO DO PROCESSO APÓS A
EDIÇÃO DA MP N. 2.180-35/2001. INCIDÊNCIA.
1. Não pode o administrado ficar sujeito indefinidamente ao
poder de autotutela do Estado, sob pena de desestabilizar um
dos pilares mestres do Estado Democrático de Direito, qual
seja, o princípio da segurança das relações jurídicas. Assim,
no ordenamento jurídico brasileiro, a prescritibilidade é a
regra, e a imprescritibilidade exceção.
2. Na ausência de lei estadual específica, a Administração
Pública Estadual poderá rever seus próprios atos, quando
viciados, desde que observado o prazo decadencial de cinco
anos. Aplicação analógica da Lei n. 9.784/99.
3. Os juros de mora devem ser fixados no percentual de
6\% ao ano na hipótese de a ação ter sido proposta após a
vigência da Medida Provisória n. 2.180-35, de 24 de agosto
de 2001, que acrescentou o art. 1º-F ao texto da Lei n.
9.494/97. Precedentes.
4. Recurso Especial parcialmente provido.”
(REsp 645.856/RS, Rel. Min. LAURITA VAZ, Quinta
Turma, DJ 13/9/2004, p. 291).

Vejamos a seqüência de argumentos contida nesse outro acórdão (REsp n. 645.856). Lá se afirma, como premissa, que "não pode o administrado ficar sujeito indefinidamente ao poder de autotutela do Estado, sob pena de desestabilizar um dos pilares mestres do Estado Democrático de Direito, qual seja, o princípio da segurança das relações jurídicas. Assim, no ordenamento jurídico brasileiro, a prescritibilidade é a regra, e a imprescritibilidade exceção".

Em apoio a essa posição, é citada lição de Celso Antônio Bandeira de Mello: ${ }^{7}$ "Isto posto, estamos em que, faltando regra específica que disponha de modo diverso,

\footnotetext{
MELlO, Celso Antônio Bandeira de. Curso de Direito Administrativo. 15. ed. São Paulo: Malheiros, 2003. p. 906-907. O autor, na obra citada, não se limita a tratar da prescrição de ações judiciais; cuida também da prescrição e da decadência quanto ao exercício de função administrativa. Aliás, ressalta o autor ser a prescrição
} 
Competências legislativas e analogia - breve ensaio a partir de decisões judiciais sobre a aplicação do art. 54 da Lei $n$. 9.784/99

ressalvada a hipótese de comprovada má-fé em uma, outra ou em ambas as partes de relação jurídica que envolva atos ampliativos de direito dos administrados, o prazo para a Administração proceder judicialmente ${ }^{8}$ contra eles é, como regra, de cinco anos, quer se trate de atos nulos, quer se trate de atos anuláveis".

No mesmo sentido, é trazido o pensamento de Hely Lopes Meirelles:9 "Mas, mesmo na falta de lei fixadora do prazo prescricional, não pode o servidor público ou o particular ficar perpetuamente sujeito a sanção administrativa por ato ou fato praticado há muito tempo. A esse propósito, o STF já decidiu que 'a regra é a prescritibilidade'. Entendemos que, quando a lei não fixa o prazo da prescrição administrativa, esta deve ocorrer em cinco anos, à semelhança da prescrição das ações pessoais contra a Fazenda Pública (Dec. 20.910/32), das punições dos profissionais liberais (Lei 6.838/80) e para a cobrança do crédito tributário (CTN, art. 174)".

Por conseguinte, conclui o acórdão: “Nessa toada, não merece reparos a decisão proferida pelo Tribunal a quo ao estabelecer o prazo decadencial de cinco anos para a Autarquia rever seus atos, em aplicação analógica da Lei $n$. 9.784/99".

Ou seja, a tese fixada pelo Tribunal no REsp 645.856 era a de que se impõe reconhecer, como inerente ao nosso Direito, prazo máximo para que a Administração anule seus atos.

Isso valeria tanto para a Administração federal, como para a estadual e a municipal. ${ }^{10}$

Assim, na falta de lei específica de cada ente da federação, aplica-se, por analogia, o prazo fixado na Lei n. 9.784/99.

Nesse caso, não se encontra no acórdão nenhum argumento no sentido de que a Lei n. 9.784/99 se aplique a Estados e Municípios - quer dizer, tenha aí seu campo de incidência.

E nem poderia ser diferente, pois a matéria de Direito Administrativo, com a exceção prevista no art. 22, XXVII, ${ }^{11}$ da Constituição Federal, é de competência legislativa privativa de cada ente da Federação, no que diz respeito à sua própria Administração.

\footnotetext{
"instituto concebido em favor da estabilidade e segurança jurídicas (objetivo, este, também compartilhado pela decadência)" (p. 898).

8 Note-se que não é esta exatamente a hipótese em questão, posto cuidar-se de anulação pela própria administração.

9 MEIRELlES, Hely Lopes. Direito Administrativo brasileiro. 27. ed. São Paulo: Malheiros, 2002. p. 650.

${ }^{10}$ Entenda-se o Distrito Federal incluído nas referências a Estados e Municípios.

${ }^{11}$ Que não inclui processo e ato administrativo em geral, assuntos da Lei n. 9.784/99.
} 
Vale aqui, num parêntese, uma ressalva conceitual: quando a Constituição prevê competência legislativa privativa por matéria, ${ }^{12}$ compreende-se que o ente competente esgote o tratamento da matéria em questão. Por isso, afirmei que a "matéria", no caso, seria "o Direito Administrativo no que diz respeito à sua própria Administração", e não "o Direito Administrativo" de modo amplo. ${ }^{13}$ Feche-se o parêntese.

A analogia invocada com normas da Lei n. 9.784/99 nada tem a ver com competência da União para legislar sobre processo ou ato administrativo, impondo suas regras a Estados e Municípios, seja privativamente, seja apenas no âmbito de normas gerais.

Com efeito, como ensina Norberto Bobbio, ${ }^{14}$ a analogia propriamente dita (analogia legis) é procedimento de auto-integração ${ }^{15}$ do Direito, pelo qual "se tira uma nova regra para um caso imprevisto" 16 a partir de uma regra singular. Ou seja, com a analogia, cria-se uma nova norma.

Nesse sentido, Bobbio distingue a analogia (analogia legis) da interpretação extensiva:

Vejamos dois exemplos. Há quem pergunte se o art. 1.577 do C. C. [italiano], que diz respeito às obrigações do locatário no tocante a reparos da casa alugada, pode estender-se, com relação a obrigações da mesma natureza, ao comodatário: se for dada resposta afirmativa, fica criada uma nova regra disciplinadora do comodato, que antes não existia. Se se perguntar, ao invés, se o art. 1.754 do C. C., que define como mediador 'aquele que coloca em contato duas ou mais partes para a conclusão de um negócio'se estende tambémàquele que 'induz à conclusão do negócio depois que as partes iniciaram os contatos por si ou por meio de outro mediador', caso se responda afirmativamente, não se criou uma regra nova, mas

\footnotetext{
${ }^{12}$ Nem sempre a técnica empregada pela Constituição para a previsão de competência legislativa privativa vale-se do critério de matéria. No caso dos Municípios (art. 30, I), sua competência privativa define-se não por matéria, mas pela área de abrangência do interesse - no caso, interesse local - ainda que haja eventual sobreposição de "matérias" com as competências privativas previstas para União ou Estados (arts. 22 e 25, $\left.\S 1^{\circ}\right)$.

${ }^{13}$ E também não seria o caso de afirmar uma competência concorrente na matéria de Direito administrativo, pois, pela técnica constitucional, a competência legislativa concorrente levaria à elaboração de normas gerais pela União, aplicáveis também aos demais entes da Federação, o que ofenderia a autonomia dos Estados e Municípios (Constituição Federal, art. 18).

${ }^{14}$ BOBBIO, Norberto. Teoria do Ordenamento Jurídico. Tradução Maria Celeste Cordeiro Leite dos Santos. Brasília: Polis e UnB, 1989.

15 "Integração cumprida através do mesmo ordenamento, no âmbito da mesma fonte dominante, sem recorrência a outros ordenamentos e com o mínimo recurso a fontes diversas da dominante" (BOBBIO, Norberto. op. cit., p. 147).

${ }^{16}$ Id. Ibid., p. 154.
} 
simplesmente se alargou o alcance da regra dada. O primeiro exemplo é de analogia, o segundo de interpretação extensiva. Com esta, nos limitamos à redefinição de um termo, mas a norma aplicada é sempre a mesma. Com aquela, passa-se de uma norma a outra. Enquanto é correto dizer que com a interpretação extensiva se ampliou o conceito de mediador, não seria entretanto correto dizer, no caso do art. 1.577 do C. C., que com a analogia se ampliou o conceito de locação. Aqui se acrescenta a uma norma específica uma outra norma específica, desembocando num gênero comum. ${ }^{17}$

E, em outra passagem, Bobbio distingue analogia legis de analogia iuris: esta, ressalta, “não obstante a identidade do nome, não tem nada a ver com um raciocínio por analogia [...] Por analogia iuris entende-se o procedimento através do qual se tira uma nova regra para um caso imprevisto não mais da regra que se refere a um caso singular, como acontece na analogia legis, mas de todo o sistema ou de uma parte dele; esse procedimento não é nada diferente daquele que se emprega no recurso aos princípios gerais do Direito". ${ }^{18}$

Em suma: a supressão de lacuna do ordenamento jurídico, recorrendo-se à analogia, não significa afirmação da incidência da lei cujos preceitos, analogicamente, são invocados.

Nesse sentido, o fato de a supressão de lacuna do Direito estadual dar-se pela invocação analógica de norma federal, sendo a lacuna em matéria de competência legislativa privativa dos Estados, não importa violação da repartição de competências.

Isso porque a aplicação de regra por analogia não se dá mediante decisão do legislador federal - que, na hipótese, não teria competência para criar regra aplicável aos Estados - mas sim por decisão do Poder Judiciário, ou da própria Administração - no caso, estadual.

Assim, ao decidir-se por analogia, não é uma norma federal que incide, mas uma norma estadual, que é inserida no ordenamento jurídico (parcial ${ }^{19}$ ) de determinado Estado federado, mediante uma decisão da autoridade competente para aplicação do Direito estadual ao caso concreto.

Essa norma estadual, criada por analogia, pode ser elaborada a partir de elementos extraídos de normas vigentes no Ordenamento Jurídico do Brasil, aí concebido

\footnotetext{
${ }_{17}$ BOBBIO, Norberto. Teoria do Ordenamento Jurídico. Tradução Maria Celeste Cordeiro Leite dos Santos. Brasília: Polis e UnB, 1989. p. 155-156.

18 Id. Ibid., p. 154.

19 Posto tratar-se de membro da federação.
} 
como um todo único, independentemente de se considerarem suas frações parciais próprias do regime federativo.

Desse modo, ainda que o acórdão no REsp n. 610.464 não explicite a idéia de analogia, só posso entendê-lo nesse sentido, que aliás é coerente com a frase contida em sua ementa quanto à aplicação do prazo de 5 anos, nos termos da Lei n. 9.784/99, e não quanto à aplicação da Lei.

Todavia, o acórdão no REsp n. 610.464, além de citar o já comentado REsp n. 645.856, cita também o AgRg no Ag n. 683.234, supostamente harmônico, mas que eu entendo equivocado em sua motivação e, nesse ponto, divergente dos anteriores, em que pese proferido pela mesma Turma. ${ }^{20}$

Eis sua ementa:
ADMINISTRATIVO. SERVIDOR PÚBLICO. PENSÃO POR MORTE. FILHA SOLTEIRA MAIOR DE 21 ANOS. DECADÊNCIA ADMINISTRATIVA. APLICAÇÃO RETROATIVA. INCIDÊNCIA DA LEI N. 9.784/99 NO ÂMBITO ESTADUAL.
Sendo o ato que concedeu a pensão anterior à Lei n. 9.784/99, o prazo qüinqüenal para sua anulação começa a contar a partir da vigência do mencionado regramento.
Possibilidade de aplicação da Lei n. 9.784/99 no âmbito estadual.
O prazo de 5 anos, estabelecido pela Lei n. 9.784/99, é contado a partir da edição da referida lei.
Agravo regimental desprovido."
(AgRg no Ag n. 683.234/RS, Rel. Min. José Arnaldo da Fonseca, Quinta Turma, DJ 5/12/2005, p. 366)

De plano, constata-se pela ementa a afirmação da "aplicação da Lei $n$. 9.784/99 no âmbito estadual’.

E da leitura da íntegra do acórdão confirma-se que não se trata de imprecisão na redação da ementa. Com efeito, afirma-se claramente que: "No que concerne à aplicação da Lei n. 9.784/99 no âmbito dos Estados-Membros, esta Corte já decidiu que é perfeitamente possível a aplicação subsidiária da referida lei no campo estadual, não havendo lei especifica, tendo em vista que se trata de norma que deve nortear toda a Administração Pública, servindo de diretriz aos seus demais órgãos".

Ora, falar em aplicação subsidiária da Lei n. 9.784/99 aos Estados não é falar em analogia. E mais, o acórdão afirma a Lei n. 9.784/99 como norma "que deve nortear

\footnotetext{
${ }^{20} \mathrm{O}$ que levanta-me a dúvida quanto à "sutileza" que apontei no texto do acórdão no REsp n. 610.464 ser mesmo intencional! E esse AgRg no AG 683.234 também cita o REsp n. 645.856 como sendo "no mesmo sentido", leitura da qual discordo.
} 
toda a Administração Pública, servindo de diretriz aos seus demais órgãos". Por outras palavras, afirma a Lei n. 9.784/99 como lei de normas gerais, aplicável a todos os níveis da federação. Sendo correta minha leitura desse último acórdão, não posso concordar com essa tese nele contida.

Entendo que toda interpretação das normas constitucionais em matéria de competência para legislar sobre Direito Administrativo deve se dar em favor da autonomia dos entes da federação. Sendo assim, a interpretação da exceção contida no inciso XXVII do art. 22 da Constituição Federal deve ser restritiva. ${ }^{21}$

${ }^{21}$ Em outro estudo que fiz sobre o tema (capítulo intitulado "contratos administrativos", para obra coletiva sobre contratos, a ser editada pelo Centro de Extensão Universitária, ainda no prelo), tive a oportunidade de assim me manifestar: "A Constituição brasileira vigente estabelece um sistema complexo de repartição de competências, prevendo tanto competências privativas de cada ente, como competências compartilhadas. Atente-se, por ora, para as competências legislativas. [\$] As competências legislativas privativas da União são arroladas, por matéria, no art. 22; as dos Estados, são tratadas de modo residual no art. 25, $\S 1^{\circ}$; já as dos Municípios são previstas, não pelo critério de matéria, mas pelo da abrangência do interesse envolvido, no art. 30, I [Ao Distrito Federal são atribuídas as competências legislativas próprias de Estados e Municípios (art. 32, $\S 1^{\circ}$ )]. [\$] As competências legislativas concorrentes da União e Estados vêm arroladas no art. 24. Quanto a elas, vale a regra de a União tratar de normas gerais aplicadas em todos os âmbitos da federação, além de normas específicas aplicáveis no nível dela própria (União). Aos Estados, cabe estabelecer suplementarmente normas específicas. E aos Municipios, cabe suplementar a legislação federal e estadual, quando o justificar o interesse local (cf. parágrafos do art. 24 e art. 30, II). [\$] Ora, em parte alguma dos dispositivos citados há referência à competência legislativa para a matéria de Direito administrativo. Isso, todavia, não deve levar à conclusão - que seria absolutamente extravagante em um Estado federal - de que tal matéria recai na competência privativa residual dos Estados. [\$] De fato, por força da regra, essencial em uma federação, da autonomia dos entes federados (Constituição Federal, art. 18), cada ente detém privativamente a competência para se auto-administrar, o que importa tanto a prática de atos materiais de administração, como a produção de legislação de Direito administrativo aplicável no respectivo âmbito. [\$] Entretanto, exceção para essa regra está expressamente prevista no art. 22, XXVII, da Constituição Federal, competindo privativamente à União legislar sobre "normas gerais de licitação e contratação, em todas as modalidades" para todos os niveis da federação. [\$] Quanto a esse dispositivo, duas observações. Em primeiro lugar, sua impropriedade técnica [ver ALMEIDA, Fernanda Dias Menezes de. Competências na Constituição de 1988. 3. ed. São Paulo: Atlas, 2005. p. 103 e segs.]: dada a sistemática da Constituição, faria mais sentido tratar essa matéria no contexto das competências concorrentes, posto ser inerente a essas competências, como visto, a repartição pelo critério das "normas gerais", sendo estas de competência da União, assegurada aos Estados competência para cuidar das questões especificas. [\$] Em segundo lugar - e mais importante - uma ressalva de indole substancial. A compreensão desse dispositivo deveria ser inspirada por sua excepcionalidade em relação à competência para legislar sobre Direito Administrativo. Ou seja, deveria ele ser interpretado, no contexto constitucional, de modo a assegurar também neste capitulo do Direito Administrativo, a máxima autonomia para os entes federativos. [\$] Nesse sentido - sem pretender aqui prender-me a uma interpretação meramente literal do texto, mas contextualizando-a, sistematicamente, no regime federalista-penso haver importante diferença decorrente do uso, pela Constituição, do vocábulo "contratação", em lugar de "contrato". [\$] Contratação é a ação de contratar. Contrato é o objeto dessa ação. [\$] Sendo assim, estariam contidas na noção de contrato, mas não na de contratação, os aspectos estruturais dos contratos administrativos (ex.: tipos contratuais, cláusulas necessárias, regime jurídico próprio). Por outro lado, contratação diria respeito a normas de regência do ato de contratar (ex.: necessidade de previsão de recursos orçamentários, respeito ao resultado do procedimento licitatório, controles externos e internos pertinentes). [\$] Essa interpretação, parece-me, seria muito mais coerente com a autonomia dos entes federativos. Contudo, não foi esse aspecto ressaltado pela doutrina em geral, que parte, implicitamente, da assimilação das noções de contrato e contratação. E mais, presentemente, trata-se de questão superada pela prática. [\$] De fato, com base na 
Se adequada ao espírito da federação a interpretação restritiva do art. 22, XXVII, descabido pretender vislumbrar como de competência da União estabelecer normas gerais em matéria de ato ou processo administrativo em geral (exceto licitação e contratação).

Esse acórdão do AgRg no Ag n. 683.234 ainda aborda outro ponto: a nãoaplicação do limite temporal para anulação de atos administrativos a casos anteriores à vigência da Lei n. 9.784/99, o que, no caso concreto, levou à possibilidade da anulação do ato sem restrição temporal.

Como visto, essa também é a conclusão do REsp n. 610.464, assim como de outros tantos julgados citados neste acórdão e no acórdão do $\mathrm{AgRg}$ no Ag n. 683.234.22

Não é, entretanto, a tese que prevalece no REsp n. 645.856. Note-se que a anulação havida neste caso concreto (REsp n. 645.856) deu-se em 2000 e o STJ confirmou a sua impossibilidade, posto terem transcorrido mais de cinco anos a partir da edição do ato que se pretendia anular (1993). E, em 2000, obviamente, não se poderia invocar o prazo da Lei n. 9.784/99, se contado a partir do início da sua vigência.

O REsp n. 645.856 traz, aliás, a citação de outras ementas de acórdãos do STJ ${ }^{23}$ no sentido do reconhecimento da impossibilidade de anulação de ato administrativo, ante transcurso de prazo qüinqüenal; alguns desses acórdãos, datados de 2003, o que evidencia a impossibilidade de, nos respectivos casos concretos, ter transcorrido o prazo de cinco anos caso se o pretendesse contar apenas após o início da vigência da Lei n. 9.784/99.

O que está por trás dessa outra questão é existência ou-não, no nosso Direito, de norma principiológica que imponha a prescritibilidade e a caducidade ${ }^{24}$ como regra geral, devendo a imprescritibilidade, por configurar exceção, ser prevista expressamente.

Explique-se melhor. As considerações que acima produzi sobre aplicação analógica do art. 54 pressupõem como premissa que se entenda a prescritibilidade e a caducidade como inerentes ao nosso ordenamento jurídico.

\footnotetext{
competência prevista no citado art. 22, XXVII, da Constituição Federal, a União editou a Lei n. 8.666/93, que, em seu art. 1", já explicita: "esta Lei estabelece normas gerais sobre licitações e contratos administrativos...". [\$] Percebe-se, portanto, que a Lei ignorou qualquer distinção entre contrato e contratação”.

${ }^{22}$ MS n. 9.112; MS n. 9157; MS n. 9.115; REsp n. 646.107; AgRg no Ag n. 575.408; AgRg no REsp n. 758.449 .

${ }^{23}$ MS n. 6.566; REsp n. 515.225; REsp n. 219.883; AgRg no REsp n. 595.627; REsp n. 628524.

${ }^{24}$ Pode-se afirmar que o art. 54 traz hipótese de caducidade (cf. MELLO, Celso Antônio Bandeira de. Curso de Direito Administrativo. 15. ed. São Paulo: Malheiros, 2003. p. 904), ainda que não haja muita precisão nas conseqüências da distinção desses conceitos em nosso Direito.
} 
Com efeito, não me parece razoável supor que a Administração possa, como regra, a qualquer tempo, anular seus atos. Isso não seria condizente com a estabilidade das relações jurídicas, que permeia principiologicamente nosso Direito.

Esse pensamento não é pacífico na doutrina. Celso Antonio Bandeira de Mello, nas passagens acima referidas, o sustenta, ${ }^{25}$ com a citação de diversos diplomas legais, tanto aplicáveis especificamente à Administração, como às relações civis em geral. No mesmo sentido, ainda que com conclusões pontualmente diversas, pode-se referir o pensamento de Hely Lopes Meirelles; ${ }^{26}$ de Maria Sylvia Zanella Di Pietro,27 de Edmir Netto de Araújo. ${ }^{28}$

Em sentido contrário, Odete Medauar afirmava em edições anteriores de sua obra: "No direito pátrio, em princípio, o ato administrativo ilegal pode ser anulado em qualquer época. Embora alguns considerem iníqua tal regra, pela pendência da situação, relembre-se que decorre do princípio da legalidade, consagrado pela Constituição Federal. Limitação temporal ao poder de anular deve estar prevista de modo explícito e não-presumido ou deduzido de prazos prescricionais fixados para outros âmbitos. Entendimento diverso traz subjacente incentivo à prática de ilegalidade, ante a possibilidade de ser consolidada pela prescrição". ${ }^{29} \mathrm{Na}$ atual edição, a Autora modificou a redação dessa passagem, afirmando que "no direito pátrio, por muito tempo, prevaleceu o entendimento no sentido da possibilidade de anular ato administrativo ilegal em qualquer época", mas ressalta que "hoje se encontram leis que fixam limites temporais ao poder de anular, em virtude, sobretudo, de princípio da segurança jurídica" e cita o exemplo do art. 54 da Lei n. 9.784/99. ${ }^{30}$

Não pretendo aqui aprofundar a questão, em tese, da existência principiológica em nosso Direito, anteriormente à Lei n. 9.784/99, de norma que imponha prazo para que a Administração anule seus atos.

Concordo que existisse, ${ }^{31}$ sobretudo por duas razões: a) pela existência de normas fixando prazo prescricional para a ação judicial que se intentasse contra a Administração, no caso, visando à anulação de ato administrativo (Decreto n. 20.910/32)

\footnotetext{
25 Ver nota 6 supra.

26 Ver nota 8 supra.

${ }^{27}$ DI PIETRO, Maria Sylvia Zanella. Direito Administrativo. 20. ed. São Paulo: Atlas, 2007. p. 683-684.

28 ARAÚJO, Edmir Netto de. Curso de Direito Administrativo. São Paulo: Saraiva, 2005. p. 483-484.

${ }^{29}$ MEDAUAR, Odete. op. cit., p 186.

${ }^{30}$ MEDAUAR, Odete. Direito Administrativo moderno. 11. ed. São Paulo: Revista dos Tribunais, 2007. p. 156.

31 Ainda que veja relevância do argumento da legalidade, invocado por Odete Medauar.
} 
- se pode a Administração invocar judicialmente a prescrição, impedindo assim que eventual interessado consiga anular ato administrativo, porque não estaria a Administração sujeita aos mesmos limites, na esfera administrativa, invertidos os pólos de interesse?; e b) pelo tratamento constitucional da imprescritibilidade como exceção, ainda que cuidando de matéria penal (Constituição Federal, art. 5, XLII e XLIV).

Mas, de fato, como mostra Odete Medauar, a questão ficou superada com a edição da Lei n. 9.784/99.

Assim, mesmo que a Lei n. 9.784/99 seja aplicável apenas no âmbito da União, resta indiscutível que nosso Direito passou a adotar hipótese específica de limite temporal para que a Administração anule seus próprios atos, justificando aplicação analógica, nos âmbitos estadual e municipal, do prazo previsto nessa Lei.

Em suma, para que se cogite de aplicação analógica desse prazo qüinqüenal, há antes que se fixar a premissa de que para Administração, em todos os níveis, impõe-se limite temporal para anulação de seus atos.

Note-se que a fixação dessa premissa não caracteriza aplicação de analogia propriamente dita (analogia legis), mas sim da analogia iuris, no sentido esclarecido por Bobbio. ${ }^{32}$ A analogia (em sentido próprio) que aqui está em questão é quanto à aplicação do prazo qüinqüenal.

E, para encerrar, voltemos àquela última questão levantada a partir dos acórdãos citados, quanto a estarem, ou-não, os atos de anulação, praticados pela Administração anteriormente à edição da Lei n. 9.784/99, sujeitos a limite temporal para sua prática.

A resposta à questão novamente exige a fixação da premissa:

a) se se considera que, mesmo antes da edição da Lei n. 9.784/99, impunhase à Administração o limite temporal para anulação - posição com a qual concordo -, é natural se invocar, para a hipótese de anulações havidas antes do escoamento do prazo introduzido pela Lei n. 9.784/99, analogia com o prazo, também qüinqüenal, constante do Decreto n. 20.910/32. Digo analogia com o prazo constante desse Decreto e não da Lei n. 9.784/99. E a razão para essa afirmação não é eventual argumento quanto à não aplicação retroativa da Lei n. 9.784/99, pois, como acima afirmado, aplicação de analogia não significa incidência da norma cujo conteúdo seja invocado analogicamente e sim criação de nova norma. A razão é que não me parece razoável exigir da Administração que atentasse para prazo que só viesse a ser fixado posteriormente, mesmo que desde

\footnotetext{
${ }^{32}$ Cf. supra.
} 
antes se soubesse que algum prazo haveria de existir. De fato, há, entre nós, entendimento pacificado quanto a os prazos que importam perecimento de direitos deverem começar a ser contados a partir da vigência da norma que os institui. ${ }^{33}$

b) se se considera que esse limite temporal somente surge em nosso Direito com a Lei n. 9.784/99, então não há que se falar em limite de tempo para que a Administração anulasse seus atos anteriormente ao esgotamento do prazo qüinqüenal que começa a ser contado com a vigência da Lei n. 9.784/99³4; ou

c) se se considera que, mesmo com a Lei n. 9.784/99, esse limite temporal não configura norma principiologicamente aplicável a Estados e Municípios, a questão nem se põe.

São Paulo, novembro de 2007.

Referências:

ARAÚJO, Edmir Netto de. Curso de Direito Administrativo. São Paulo: Saraiva, 2005.

BOBBIO, Norberto. Teoria do Ordenamento Jurídico. Tradução de Maria Celeste Cordeiro Leite dos Santos. Brasília: Polis e UnB, 1989.

DI PIETRO, Maria Sylvia Zanella. Direito Administrativo. 20. ed. São Paulo: Atlas, 2007.

HORBACH, Carlos Bastide. Comentários aos arts. 9 a 14 da Lei n. 10.257/01. In: MEDAUAR, Odete; ALMEIDA, Fernando Dias Menezes de. (Coords.). Estatuto da Cidade Lei 10.257, de 10.07.2001 - Comentários. 2. ed. São Paulo: Revista dos Tribunais, 2004.

KELSEN, Hans. Teoria Pura do Direito. Tradução de João Baptista Machado. Coimbra: Arménio Amado, 1962. v. II.

MEDAUAR, Odete. Direito Administrativo moderno. 11. ed. São Paulo: Revista dos Tribunais, 2007.

\footnotetext{
${ }^{33}$ Nesse sentido a questão mais recentemente resolvida pelo Supremo Tribunal Federal foi a relativa ao termo inicial do prazo da usucapião prevista no art. 183 da Constituição Federal, tal como constante dos RE n. 145.004, RE n. 206.659, RE n. 191.603, RE n. 187.913, RE n. 214.851, RE n. 217.414, RE n. 221.822 (cf. comentários feitos por HORBACH, Carlos Bastide. Comentários aos arts. $9^{\circ}$ a 14 da Lei n. 10.257/01. In: MEDAUAR, Odete; ALMEIDA, Fernando Dias Menezes de. (Coords.). Estatuto da Cidade - Lei n. 10.257, de 10.07.2001 - Comentários. 2. ed. São Paulo: Revista dos Tribunais, 2004. p. 133-134). No caso, porém, a discussão resta meramente teórica, pois houve coincidência entre o prazo anteriormente existente e o prazo que veio a ser previsto pela Lei n. 9.784/99.

${ }^{34}$ Ver nota anterior.
} 
. Direito Administrativo moderno. 8. ed. São Paulo: Revista dos Tribunais, 2004.

. O Direito Administrativo em evolução. 2. ed. São Paulo: Revista dos Tribunais, 2003.

. A processualidade no Direito Administrativo. São Paulo: Revista dos Tribunais, 1993

MELLO, Celso Antônio Bandeira de. Curso de Direito Administrativo. 15. ed. São Paulo: Malheiros, 2003.

MEIRELLES, Hely Lopes. Direito Administrativo Brasileiro. 27. ed. São Paulo: Malheiros, 2002. 